Bulletin UASVM Food Science and Technology 70(2)/2013, 147-148

ISSN-L 2344-2344; Print ISSN 2344-2344; Electronic ISSN 2344-5300

\title{
The Manufacturing Process and Quality Control of a Holland Type Cheese
}

\section{Cristina Anamaria SEMENIUC, Ancuţa Mihaela ROTAR, Carmen POP, Ramona SUHAROSCHI, Sorin APOSTU}

\author{
Faculty of Food Science and Technology, University of Agricultural Sciences and Veterinary \\ Medicine Cluj-Napoca, 3-5 Calea Mănăştur Street, 400372, Cluj-Napoca, Romania; \\ cristinasemeniuc@yahoo.com
}

\begin{abstract}
The aim of this study was to evaluate the influence of storage time on physicochemical shelf-life of Holland type cheese. Cheese samples were stored in ripening room for up to 30 days. Physicochemical parameters of cheese were assessed at 19 and 30 days of storage. Samples were analyzed for titratable acidity, fat in dry matter content, protein and salt content. No significant changes were observed in physicochemical properties during the ripening process.
\end{abstract}

Keywords: Holland type cheese, manufacturing, process, quality control

Introduction. Currently, in Romania are produces a number of Dutch, French or Italian chesses. Holland type cheese is one of them. It is similar with Edam cheese.

Edam is a ripened firm/semi-hard cheese (CODEX STAN 265-1966) that originated in the Netherlands. The body has a near white or ivory through to light yellow or yellow colour and a firm-textured (when pressed by thumb) texture, suitable for cutting, with few more or less round rice to pea sized (or mostly up to $10 \mathrm{~mm}$ in diameter) gas holes, distributed in a reasonable regular manner throughout the interior of the cheese, but few openings and splits are acceptable. The shape is spherical, of a flat block or of a loaf (CODEX STAN 2651966).

Aims and objectives. The research aims was to investigate changes in selected quality attributes of the Holland type cheese during ripening.

The objectives are to establish the quality of raw milk used for cheese manufacturing and the quality of final product, Holland type cheese.

Materials and methods. For the experiment cheese samples were collected from a dairy factory that produced this type of cheese. The content of fat, protein, salt and titratable acidity were tested at the middle and late stage of ripening (at 19 and 30 days of storage).

The content of fat $(\mathrm{F})$, protein $(\mathrm{P})$ and solid non fat $(\mathrm{SNF})$ of raw milk was determined by using LactoStar analyzer (Funke-Gerber, Berlin, Germany).

Titratable acidity (expressed as Thörner degree, ${ }^{\circ} \mathrm{T}$ ) was determined using the method described by SR 2418:2008.

Density of raw milk was assessed using a thermolactodensimeter (Funke-Gerber, Berlin, Germany).

The content of protein $(\mathrm{P})$ in cheese was determined by the Kjeldahl method.

The content of fat in dry mater (FDM) was calculated after determination of the total dry matter (by oven drying method) and the fat content (by the Gerber method).

\section{Results and Discussion}

Raw milk used for cheese manufacture meet the Romanian standard requirements (fat content $>3.2 \%$, protein content $>3.2 \%$, solid non fat content $>8.5 \%$, density $>1.029$ $\mathrm{g} / \mathrm{cm}^{3}$, titratable acidity $\left.<19^{\circ} \mathrm{T}\right)$. 
The protein and fat content in dry matter showed a slight decrease at the late stage of ripening, instead, the salt content a slight increase; storage conditions in the ripening room may be responsible for the loss of nutrients and water (via volatilization) during storage.

Titratable acidity, a freshness indicator, increased with $10^{\circ} \mathrm{T}$ at the late stage of ripening as a result of lactose decomposition to lactic acid.

\section{Conclusion}

The results revealed that raw milk used for the production of cheese corresponded to standard requirements (SR 2418:2008).

Physicochemical properties of cheese showed no significant changes with ripening.

\section{REFERENCES}

1.CODEX STAN 265-1966 - Codex standard for Edam

2.SR 2418:2008 - Lapte crud integral. Cerinţe de calitate 